\title{
Mechanical Engineering in Ancient Egypt, Part 45: Birds Statues (Falcon and Vulture)
}

Galal Ali Hassaan

(Emeritus Professor), Department of Mechanical Design \& Production, Faculty of Engineering, Cairo

University, Giza, Egypt

\begin{abstract}
The evolution of mechanical engineering in ancient Egypt is investigated in this research paper through studying the production of statues and figurines of falcons and vultures. Examples from historical eras between Predynastic and Late Periods are presented, analysed and aspects of quality and innovation are outlined in each one. Material, dynasty, main dimension (if known) and present location are also outlined to complete the information about each statue or figurine.
\end{abstract}

Keywords: Mechanical engineering, ancient Egypt, falcon statues, vulture statues

\section{INTRODUCTION}

This is the $45^{\text {th }}$ paper in a scientific research aiming at presenting a deep insight into the history of mechanical engineering during the ancient Egyptian civilization. The paper handles the production of falcon and vulture statues and figurines during the Predynastic and Dynastic Periods of the ancient Egypt history. This work depicts the insight of ancient Egyptians to birds lived among them and how they authorized its existence through statuettes and figurines.

Smith (1960) in his book about ancient Egypt as represented in the Museum of Fine Arts at Boston presented a number of bird figurines including ducks from the Middle Kingdom, gold ibis from the New Kingdom and a wooden spoon in the shape of a duck and lady from the New Kingdom [1]. Smith (1994) in his book about the country life in ancient Egypt presented a number of bird figurines including a small ibis, eagle, ostrich and a setting statue for Horus from the $12^{\text {th }}$ Dynasty [2]. Arnold (1995) in his study on Egyptian bestiary presented a number of bird statuettes including a perfume vessel in the shape of two trussed ducks from the Middle Kingdom, cosmetic vessels in the shape of ducks from the $18^{\text {th }}$ Dynasty, Thoth statue from the Ptolemaic Period, falcon from the $30^{\text {th }}$ Dynasty and swallow from the Ptolemaic Period [3]. Fay (1998) in her paper about Egyptian duck flasks studied a number of duck-shaped flasks in display in the Metropolitan Museum of Art. The author presented flasks in the form of a pair of plucked ducks from the $17^{\text {th }}$ Dynasty, flasks in the form of plucked ducks from the $18^{\text {th }}$ dynasty, duck-shaped dish from the $18^{\text {th }}$ Dynasty and $200 \mathrm{~mm}$ duckling flask from the $17^{\text {th }}$ Dynasty [4].

Redpoll (2008) posted an article about the bird Gods of ancient Egypt. He stated that the ancient Egyptians personified many of their major Gods as birds. He outlined some of the bird Gods such as: Horus (as falcon/hawk), Geb (goose), Ba (heron), Maat (ostrich) and Nekhbet (vulture) [5]. Sniper (2009) posted an article about the sacred bird of Egypt. He traced the attitude of ancient Egyptians towards the ibis and how they, even, mummified and placed it in the royal tombs [6]. Lesuer (2012) in his book about birds in ancient Egypt presented a wooden-painted statuette for a Ba-bird from the Late Period located in the Oriental Institute Museum of the University of Chicago [7]. Janek (2013) studied the existence of three kinds of ibis species in ancient Egypt. He presented material evidence for the existence of each kind in Egypt [8]. Janak (2014) studied the Ba-bird which was counted among the most important Egyptian religious concepts. He investigated how the Ba was depicted in ancient Egypt and how they used it as a hieroglyphic sign [9]. 

Vulture)"

Van Hilten (2015) pointed out that analysing the mummified animals and birds recovered from ancient Egyptian tombs helps researchers to understand better their role in the ancient Egyptian society as religious offerings. He analyzed the mummy's last meal of a bird [10]. Seawright (2017) wrote an article in Tour Egypt about animals and Gods of ancient Egypt. She presented the falcon/hawk (as Horus), goose (as Geb), ibis (as Thoth), ostrich (as Maat) and vulture (as Nekhbet) [11].

\section{FALCON STATUETTES AND STATUES}

Ancient Egyptians had a great appreciation to the falcon since very early times from Predynastic to the end of the Dynastic Periods and even through the Ptolemaic Period. Examples are presented here about authorizing the falcon bird in ancient Egypt through figurines, statuettes and statues:

- The first example is a $13 \mathrm{~mm}$ length amazonite falcon amulet from Naqada I/Naqada II (36503300 BC) in display in the Museum of Fine Arts at Boston and shown in Figure 1 [12]. The design is primitive, however, it has a very important characteristic of the ancient Egyptian designs. That is rounding all the surfaces not to harm the user. The ancient Egyptian designer new this characteristic from more than 5300 years before all the recent nations.

- The second example is a $72 \mathrm{~mm}$ quartzite falcon figurine from Naqada III/ $/{ }^{\text {st }}$ Dynasty (3300-2900 BC) in display in the Metropolitan Museum of Art at NY and shown in Fig.2 [13]. Again, the design is primitive, the eyes location is engraved and all the surfaces are perfectly rounded.

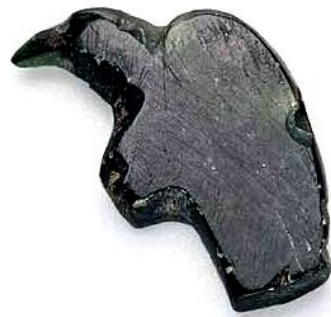

Figure1. Falcon amulet from Naqada I/II [12].

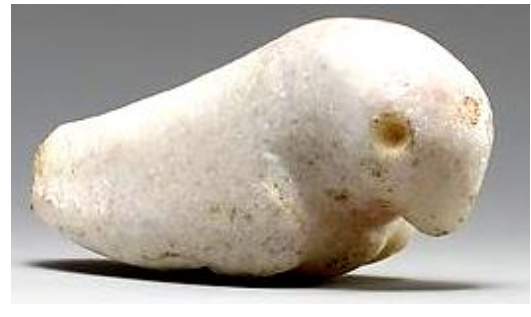

Figure2. Falcon figurine from Naqada III// ${ }^{\text {st }}$ Dynasty[13].

- The third example is a golden falcon statue of Queen Hetepheres from the $4^{\text {th }}$ Dynasty of the Old Kingdom (2600 BC) in display in the Egyptian Museum at Cairo and shown in Fig.3 [14]. From now, started the sophisticated designs of the birds indicating the development of the production technology and the wealth of the Kings during the Old Kingdom, the builders of the pyramids. The falcon is shown spreading its wings with clearly identified feathers. The falcon is looking to its right side and holding the chin sign between its fingers. This is a master piece indicating the level of mechanical engineering technology more than 4600 years ago.

- The fourth example is a $375 \mathrm{~mm}$ height golden falcon head from the $6^{\text {th }}$ Dynasty (2323-2150 BC) found in Horus Temple at Nekhen and in display in the Egyptian Museum at Cairo and shown in Fig.4 [15]. This is a high quality piece produced professionally from gold and the eyes were simulated accurately using obsidian. The designer showed the falcon wearing a two-feathers crown with cobra on its front and a necklace.

- The fifth example is falcon figurines in a necklace for Princess Sithathor during the reign of Senwosret II (1887-1878 BC), the $4^{\text {th }}$ King of the $12^{\text {th }}$ Dynasty in display in the Metropolitan Museum of Art and shown in Fig.5 [16]. The pectoral was manufactured from gold and inlaid with turquoise, lapis lazuli, carnelian and garnet. The main items in the design are the two falcons. The necklace is completely symmetric about a vertical axis through its centroid. Each falcon carries a solar disc on its head, holding a shen symbol by the its right claws and supporting the shrine of the Princess by its left leg. There is an Ankh symbol and a cobra between each falcon and the Cartouche of the Pharaoh.

- The sixth example is a faience falcon amulet from the $12^{\text {th }}$ Dynasty (1991-1783 BC) in display in the Museum of Fine Arts at Boston and shown in Fig.6 [17]. The falcon was shown standing with eye marked in black. At least two colours were used in producing the falcon. 
Galal Ali Hassaan "Mechanical Engineering in Ancient Egypt, Part 45: Birds Statues (Falcon and Vulture)"

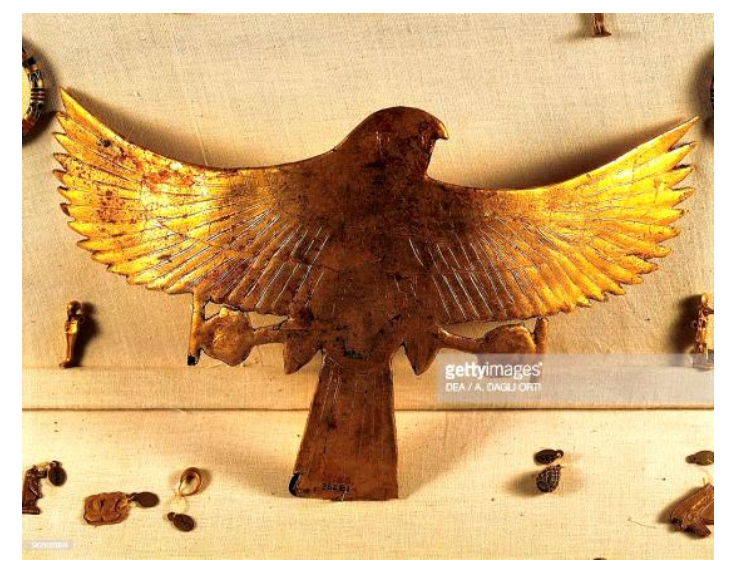

Figure3. Falcon statue from $4^{\text {th }}$ Dynasty [14].

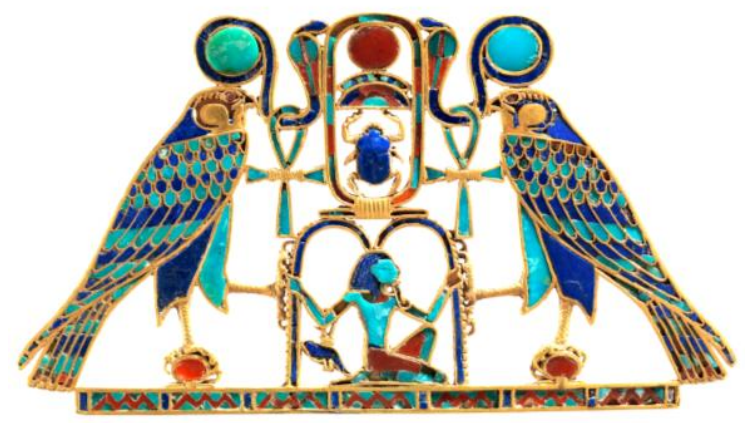

Figure5. Falcon necklace from $12^{\text {th }}$ Dynasty [16].

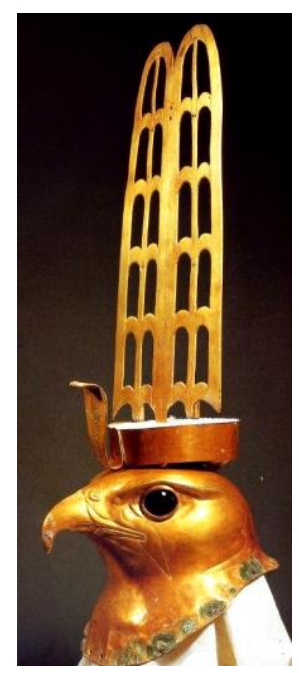

Figure4. Falcon head from $6^{\text {th }}$ Dynasty[15].

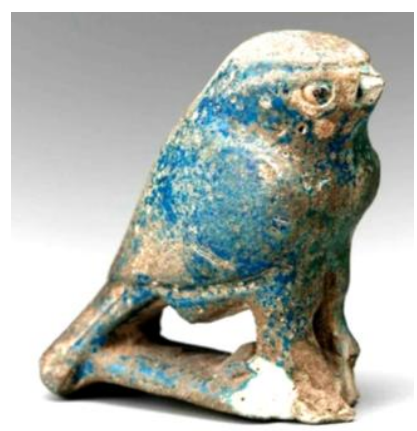

Figure6. Falcon from $12^{\text {th }}$ Dynasty[17].

- The seventh example is a $250 \mathrm{~mm}$ diameter pectoral of Senebtisi from Late 12th Dynasty - Early 13th Dynasty (1850-1775 BC) in display in the Metropolitan Museum of Art and shown in Fig.7 [18]. The pectoral was manufactured from gold, faience, carnelian and turquoise. The designer used two falcon heads manufactured from gilded plaster as a buckle.

- The eighth example is an $87 \mathrm{~mm}$ height falcon statuette wearing a Double Crown from the 12th Dynasty - 17th Dynasty Periods (1850-1550 BC) in display in the Metropolitan Museum of Art and shown in Fig.8 [19]. It was produced using electrum and plaster. The mechanical designer shoed the falcon as a symbol for the unified Egypt through putting the Double Crown of Unified Egypt on the head of the falcon.

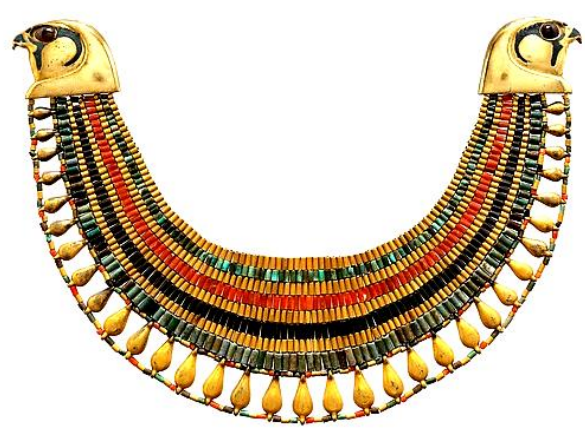

Figure7. Pectoral from $12^{\text {th }}$ Dynasty [18].

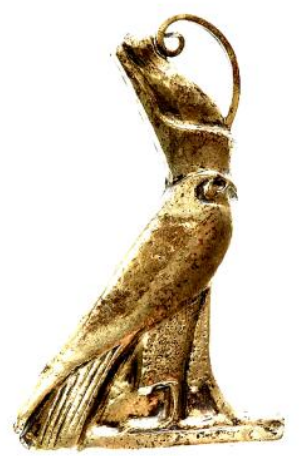

Figure8. Falcon from $12^{\text {th }}$ Dynasty [19].

- The ninth example is a $65 \mathrm{~mm}$ height ceramic female figurine with a falcon head from the Second Intermediate Period (1640-1532 BC) from LACMA collections and shown in Fig.9 [20]. It is probable that the designer wanted to say through this design that this is a powerful woman and she is under the protection of Horus.

- The tenth example is a canopic jar with lid taking the shape of a falcon from the New Kingdom (1570-1085 BC) shown in Fig.10 [21]. No dimensions, material or present location are given !!. 
Galal Ali Hassaan "Mechanical Engineering in Ancient Egypt, Part 45: Birds Statues (Falcon and Vulture)"

The designer used an ovoid shape for the jar including its led and used its body as a medium hieroglyphic inscriptions in symmetric columns while the falcon is rising its head towards the sky.

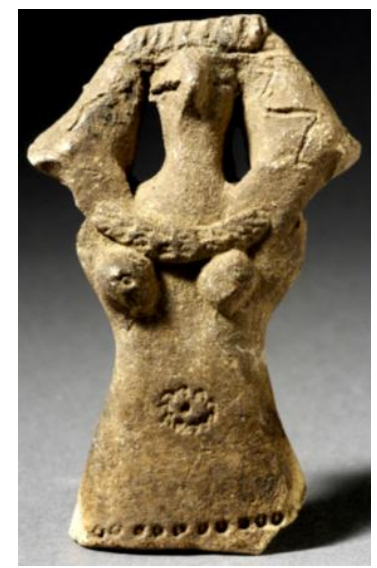

Figure9. Female with falcon head [20].

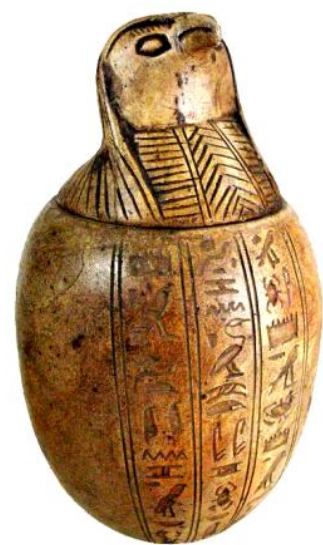

Figure10. Canopic jar from New Kingdom [21].

- The eleventh example is a falcon pectoral for Tutankhamun, the 13th Pharaoh of the 18th Dynasty (1332-1323 BC) in display in the Egyptian Museum at Cairo and shown in Fig.11 [22]. Here, we are in the 18th Dynasty, the dynasty of wealth and high mechanical technology. This master piece represents the falcon spreading its wings in a curvature manner, carrying a solar disc on its head and holding a shen sign in its claws. The designer used multi colours through using six different materials: gold, lapis lazuli, carnelian, turquoise, obsidian and glass. This is a very complex design and consists of hundreds of components with assembly technique which is outstanding to survive for more than 3300 years withstanding all the environmental effects.

- The twelfth example is a $25 \mathrm{~mm}$ height lapis lazuli falcon statuette from the New Kingdom (1450-1185 BC) in display in the Walters Art Museum and shown in Fig.12 [23]. Here the carver used a single stone to produce this statuette showing all its details including its feathers.

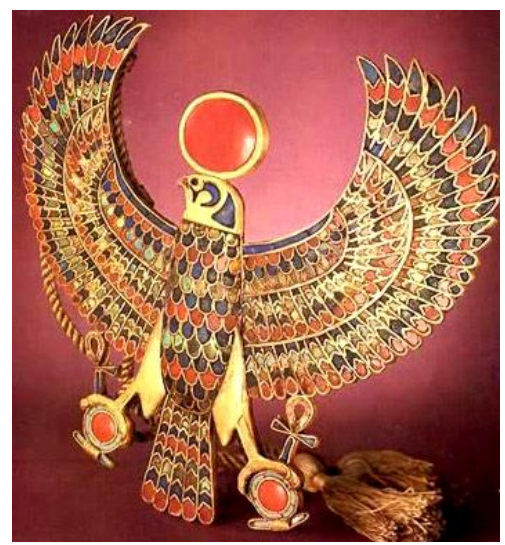

Figure11. Falcon pectoral of Tut [22].

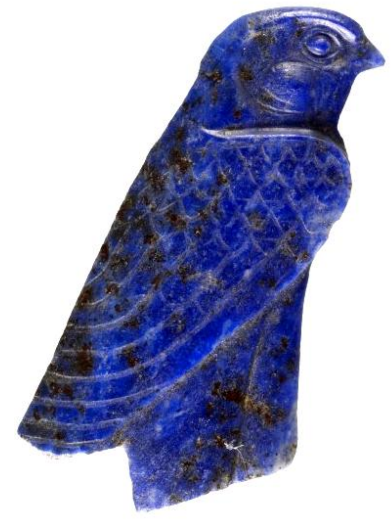

Figure12. Falcon from New Kingdom [23].

- The thirteenth example is a falcon statue from the reign of Amenhotep II, the $7^{\text {th }}$ Pharaoh of the 18th Dynasty (1425-1398 BC) in display in the Busee Royal de Mariemont at Belgium shown in Fig.13 [24]. No details are given about this falcon statue. Probably, it is a colossal statue taken from one of the 18th Dynasty Temples. But, how can this happen ?. A lot of work is required by Egyptologists to clarify all the missing aspects about the ancient Egyptian artefacts.

- The fourteenth example is a $2.31 \mathrm{~m}$ height granite falcon statue protecting Ramses II as a child from the 19th Dynasty (1290-1224 BC) in display in the Egyptian Museum at Cairo and shown in Fig.14 [25,26]. This is a highly professionally carved using the hard granite rock. The falcon is depicted in two different colours and the young Ramses II is shown putting his finger in his mouth and in squat setting. All the details of the boy and the falcon were accurately carved with smooth surfaces specially for the boy. 
Galal Ali Hassaan "Mechanical Engineering in Ancient Egypt, Part 45: Birds Statues (Falcon and Vulture)"

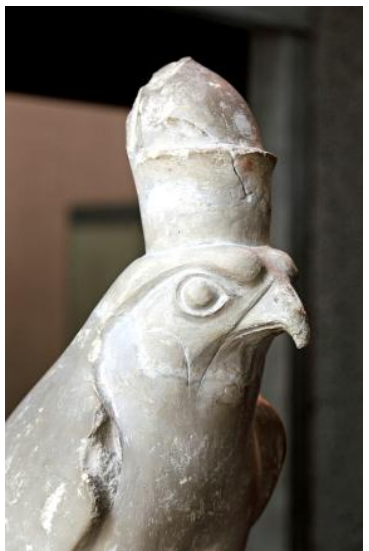

Figure13. Falcon from $18^{\text {th }}$ Dynasty [24].

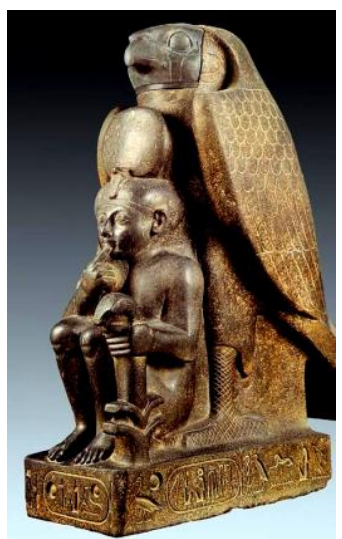

Figure14. Falcon from New Kingdom [25].

- The fifteenth example is a canopic jar with a falcon head lid belonging to Psusennes I, the 3rd Pharaoh of the 21st Dynasty (1047-1001 BC) in display in the Egyptian Museum at Cairo and shown in Fig. 15 [27]. The jar was carved from alabaster while the lid was produced from gilded bronze taking the shape of a falcon head with cobra on its forehead.

- The sixteenth example is a wooden falcon figurine from the Late Period (760-332 BC) in display in the Museum of Fine Arts at Boston and shown in Fig.16 [28]. Even though, it was produced from painted wood, it looks wonderful with very clear details of the falcon.

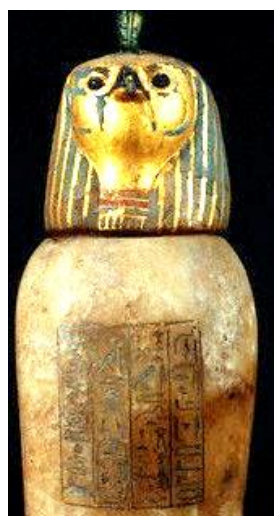

Figure15. Canopic jar from $21^{\text {st }}$ Dynasty [27].

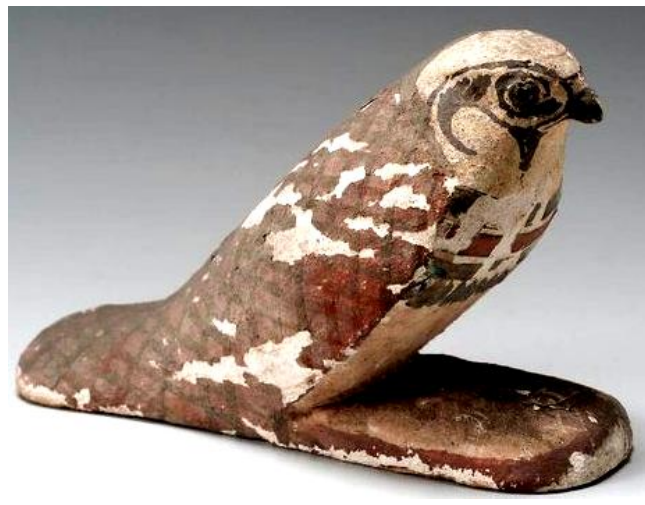

Figure16. Falcon from New Kingdom [28].

- The seventeenth example is a statue of Taharqa, the 5th Pharaoh of the 25th Dynasty (690-664 BC) presenting offerings to the falcon in display in the Louvre Museum at Paris and shown in Fig.17 [29]. The statuette was produced from bronze and the falcon was gilded by gold leaf. The statuette represents the high casting technology attained in ancient Egypt because of the complexity of the product specially the Pharaoh who was shown kneeling and presenting offerings. I have sent to two specialists in casting and production engineering in Cairo University asking them about the possible production of this unit nowadays.

- The eighteenth example is a $270 \mathrm{~mm}$ bronze falcon statue produced during the Late - Ptolemaic Periods (664-30 BC) sold in a sale for 13,750 US\$ in 5 December 2012 at NY and shown in Fig.18 [30]. The falcon was shown standing on a base over a pillar with parallelogram foot and wearing the Double Crown of ancient Egypt. The falcon was professionally casted showing all its details in two colours. This is another example on the high technology attained in ancient Egypt regarding the casting process.

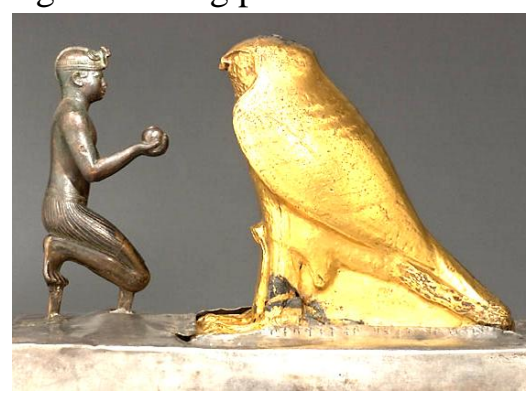

Figure17. Falcon from Late Period [29].

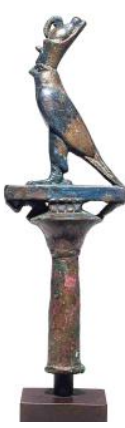

Figure18. Falcon from Late-PtolemaicPeriods [30]. 
Galal Ali Hassaan "Mechanical Engineering in Ancient Egypt, Part 45: Birds Statues (Falcon and Vulture)"

- The nineteenth example is a $130 \mathrm{~mm}$ bronze falcon statuette from the $26^{\text {th }}$ Dynasty (664-525 BC) sold in a sale for 75,803 US\$ on 26 April 2012 at London and shown in Fig.19 [31]. Again, the designer showed the falcon wearing the Double Crown of ancient Egypt and standing on a base. The designer could show professionally the details of the falcon using probably the casting process.

- The twentieth and last example is a $0.72 \mathrm{~m}$ greywacke falcon statue protecting Nectanebo II, the 3rd Pharaoh of the 30th Dynasty (360-343 BC) in display in the Metropolitan Museum of Art and shown in Fig.20 [32]. The designer showed the falcon wearing the Double Crown of Ancient Egypt and holding the Pharaoh between its legs. The carver could professionally carve the statue using a hard stone material (greywacke) showing all the details of the falcon and the standing Pharaoh as clear in the zoomed view.

\section{VULTURE STATUES}

The ancient Egyptians had a great appreciation for the vulture since the Predynastic Period where they considered it as a deity called Nekhbet and built a shrine for it during Naqada III Period (3200-3100 BC). This appreciation continued up to the New Kingdom where it was put with the cobra within the Pharaoh's Crowns [33]. This appreciation will be demonstrated through statues and figurines for the Middle, Second Intermediate and New Kingdom Periods.

- The first example is a vulture jar from the 12th Dynasty (1976-1794 BC) in display in the Fitzwilliam Museum at Cambridge and shown in Fig.21 [34]. This is a unique product in which the designer showed two vultures facing each other and spreading their wings around the jar, supporting the jar neck by their beaks and sharing holding a symbol together by their claws. The dimensions and the material are not assigned !. Most probably, this is a stone jar carved with outstanding profession.

- The second example is a pectoral for Princess Mereret, daughter of Senusret III, the 5th King of the 12th Dynasty (1878-1839 BC) in display in the Egyptian Museum at Cairo and shown in Fig.22 [35]. . It was produced from gold, turquoise, carnelian, amethyst and lapis lazuli. The designer used a wonderful shrine holding two lions having a falcon head with Egypt enemies under their feet and supporting the Cartouche of the Pharaoh by one leg for each of them while a vulture in the top is spreading its wings over them and holding a shen symbol in each leg claws.

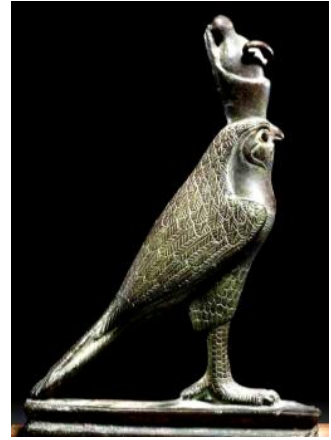

Figure19. Falcon from $26^{\text {th }}$ Dynasty [31].

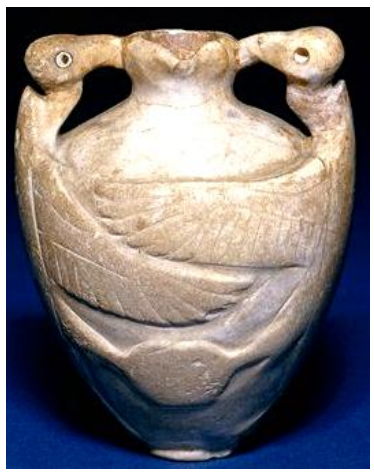

Figure21. Vulture jar from $12^{\text {th }}$ Dynasty [34].
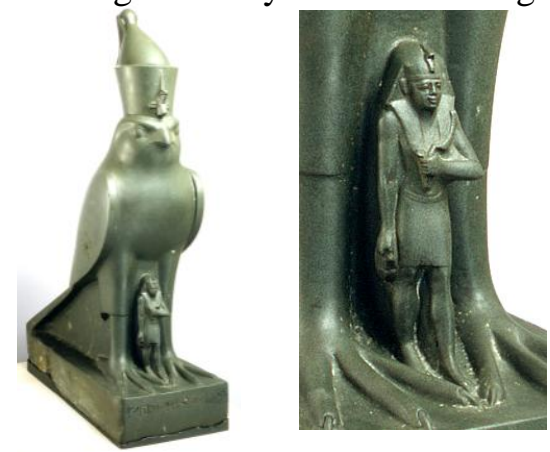

Figure20. Falcon from $30^{\text {th }}$ Dynasty [32].

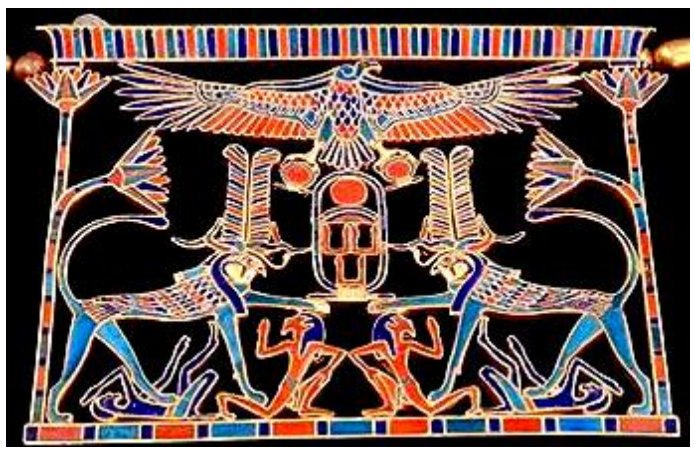

Figure22. Falcon from $30^{\text {th }}$ Dynasty [35].

- The third example is a $73 \mathrm{~mm}$ diameter bracelet of Queen Ahhotep, Great Royal Wife of King Seqenenre Tao (1560-1530 BC) from the $17^{\text {th }}$ Dynasty in display in the Egyptian Museum at Cairo and shown in Fig.23 [36]. It is manufactured from gold and inlaid by lapis lazuli, carnelian, 

Vulture)"

turquoise and glass. This is an outstanding mechanical design outlined by the ancient Egyptian mechanical engineer more than 3540 years ago. The main item in the design is the vulture. The circular band of the bracelet is the vulture wings, the vulture body is decorating the bracelet and giving a symbol for Royalty and strength. The vulture is holding a shen sign in the claws of each leg. The five materials used in the production of the bracelet gave a combination of multi-colours adding beauty to the product and indicating the high technology attained by the ancient Egyptians to produce multi-materials products capable of sustaining the environments for thousands of years.

- The fourth example is a Nekhbet necklace for Tutankhamun, the $13^{\text {th }}$ Pharaoh of the $18^{\text {th }}$ Dynasty (1332-1323 BC) in display in the Egyptian Museum and shown in Fig.24 [37]. We are here in the vicinity of the $18^{\text {th }}$ Dynasty where the high mechanical technology and wonder of the ancient Egyptian products. The mechanical designer used the vulture as the unique element in this necklace. He selected the materials of his product to give the amazing image shown in Fig.24: gold inlaid by lapis lazuli, carnelian, obsidian and glass. The designer bent the vulture wings downward to decrease the width of the necklace pendant. He set the feathers of the wing to increase gradually from the origin of the wing to its tip in blue colour giving more beauty to the necklace. He covered the body and tail with uniform feathers (small size for the body and relatively long feathers for the tail). The vulture is holding two shens and turning its head to its right side.

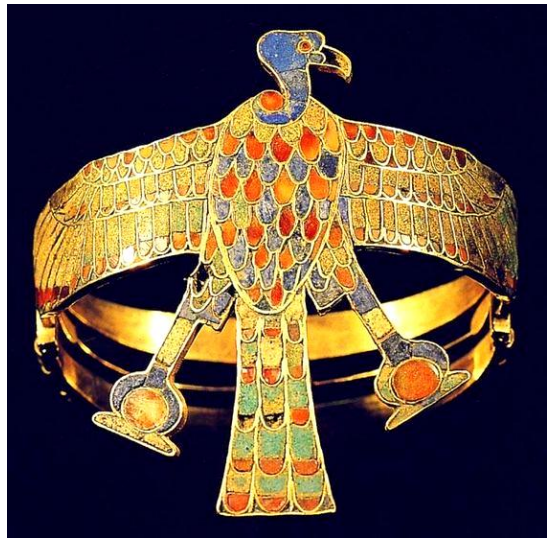

Figure23. Vulture bracelet from $17^{\text {th }}$ Dynasty [36].

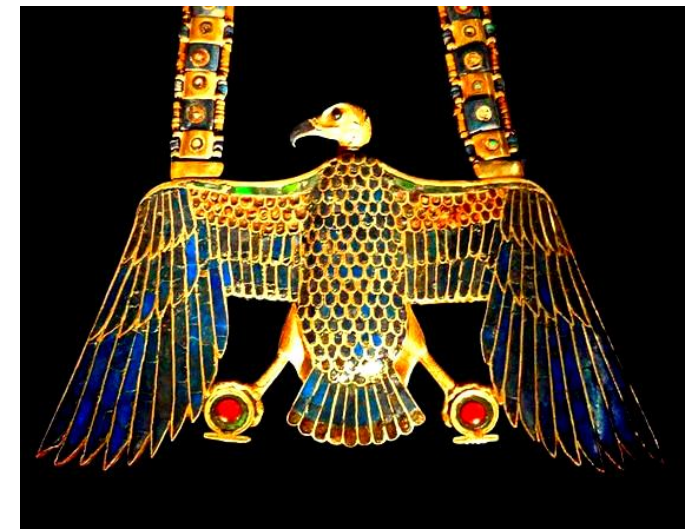

Figure24. Necklace from $18^{\text {th }}$ Dynasty [37].

- The fifth example is a gilded wooden shield of Pharaoh Tutankhamun of the $18^{\text {th }}$ Dynasty in display in the Egyptian Museum and shown in Fig.25 [38]. The designer showed the Pharaoh as a lion with the head of the Pharaoh wearing the Double Crown of ancient Egypt and trampling two of Egypt enemies by his four feet. He showed two strong birds spreading their wings above the Pharaoh: falcon and vulture.

- The sixth example is a diadem with vulture and cobra for Pharaoh Tutankhamun of the $18^{\text {th }}$ Dynasty in display in the Egyptian Museum at Cairo and shown in Fig.26 [39]. It was produced from gold and inlaid by six other materials: obsidian, carnelian, malachite, chakedony, lapis lazuli and glass. The designer put in the front figurines of a vulture and a cobra indicating royalty and power. The body of the diadem was decorated by flowers within two coloured-interchanging borders.

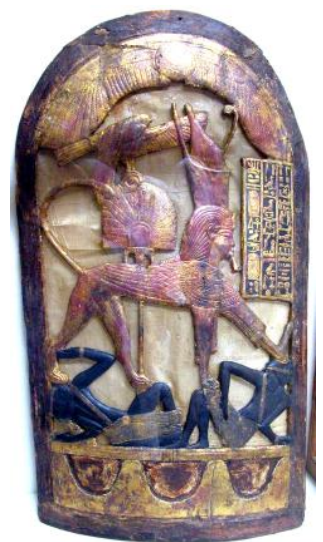

Figure25. Shield from $18^{\text {th }}$ Dynasty [38].

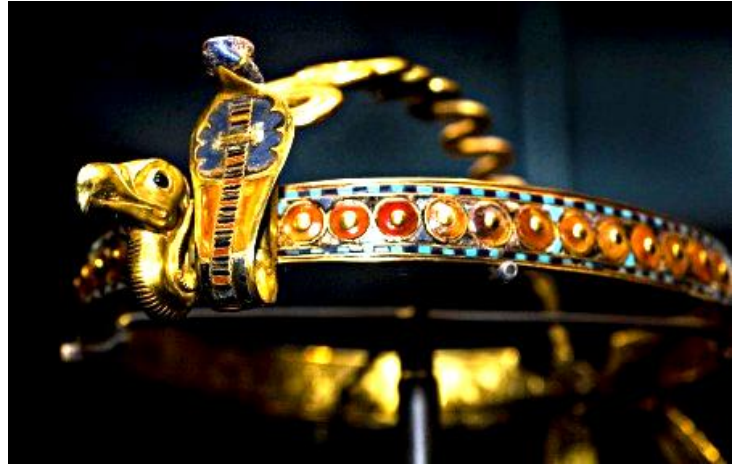

Figure26. Diadem from $18^{\text {th }}$ Dynasty [39]. 
Galal Ali Hassaan "Mechanical Engineering in Ancient Egypt, Part 45: Birds Statues (Falcon and Vulture)"

- The seventh and last example is a $32 \mathrm{~mm}$ width gold vulture amulet from the Third Intermediate Late Periods (1000-300 BC) showed in Fig.27 [40]. The designer showed the vulture spreading its wings and holding a shen in each leg-claws. It was inlaid for the eyes, wings and shen without details for the inlay materials.

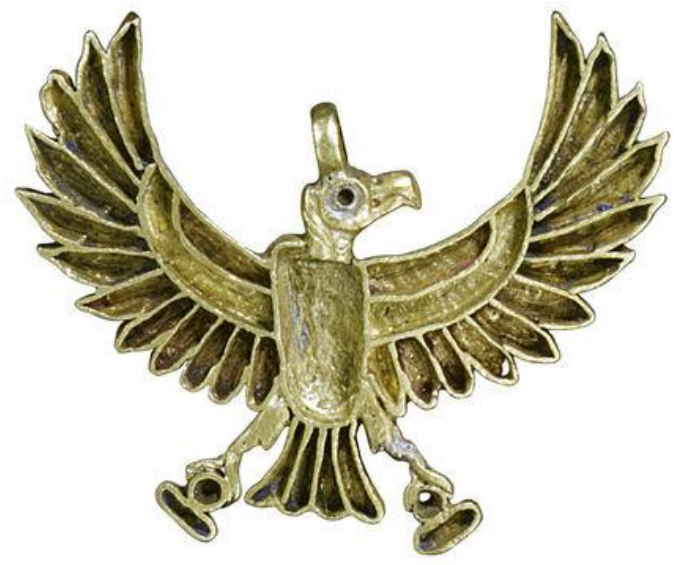

Figure27. Amulet from $3^{\text {rd }}$ Intermediate-Late Periods [40].

\section{CONCLUSION}

- The evolution of mechanical engineering during the ancient Egypt history was investigated in this research paper through the production of falcon and vulture statues and figurines.

- The ancient Egyptians produced falcon figurines and applications documented from the time of Naqada I and continued down to the Late Period.

- They produced a lot of materials in producing and inlaying falcon figurines such as: amazonite, quartzite, alabaster, granite, greywacke, plaster, wood, faience, bronze, gold, turquoise, lapis lazuli, carnelian, garnet, obsidian and glass.

- They produced falcon-based units in the form of amulet, figurine, statue, necklace, pectoral, statuette with Double Crown, canopic jar lid and female head.

- They used the falcon as a main element in the jewellery industry during the $12^{\text {th }}$ and $18^{\text {th }}$ Dynasties.

- Vulture figurines started to appear during the $12^{\text {th }}$ Dynasty.

- They used the vulture as an item in jar, jewellery and shield production.

- They used various materials in the production and inlay of vulture items including: malachite, chakedony, wood, gold, turquoise, carnelian, amethyst, lapis lazuli, obsidian and glass.

- They could produce wonderful jewellery based on using falcon and/or vulture as main item during the $12^{\text {th }}$ and $18^{\text {th }}$ Dynasty.

- Falcon statues continued to appear down to the end of the Late Period.

- Vulture-based jewellery continued in production down to the beginning of the Late Period.

\section{REFERENCES}

[1] W. Smith, "Ancient Egypt as represented in the Museum of Fine arts, Boston", Museum of Fine Arts, Boston, 1960.

[2] W. Smith, "Country life in ancient Egypt", Museum of Fine Arts, Boston, 1994.

[3] D. Arnold, "An Egyptian Bestiary", The Metropolitan Museum of Art Bulletin, pp.7-64, Spring 1995.

[4] B. Fay, "Egyptian duck flasks of blue anhydrite", Metropolitan Museum Journal, vol.33, pp.2348, 1998.

[5] H. Redpoll, "The bird Gods of ancient Egypt", https://hoaryredpoll.wordpress.com/ 2008/06/09/ the-bird-gods-of-ancient-egypt/, October 2009. 
Galal Ali Hassaan "Mechanical Engineering in Ancient Egypt, Part 45: Birds Statues (Falcon and Vulture)"

[6] S. Sniper, "The sacred bird of Egypt", http://www.freerepublic.com/focus/chat/2370607/posts , October 2009.

[7] R. Lesuer (Editor), "Between heaven and earch: Birds in ancient Egypt", Oriental Institute Museum Publication 35, 2012.

[8] J. Janak, "Northern bald ibis (Akh-bird)", UCLA Encyclopedia of Egyptology, 2013.

[9] J. Janak, "Saddle-billed stork (Ba-bird)", UCLA Encyclopedia of Egyptology, 2014.

[10] L. Van Hilten, "Why ancient Egyptians bred birds of prey", Elsevier, 2015.

[11] C. Seawright, "Animals and the Gods of ancient Egypt", Tour Egypt, http://www.touregypt.net/ featurestories/animalgods.htm , 2017.

[12] Museum of Fine Arts, "Falcon amulet", http://www.mfa.org/collections/object/falcon-amulet347431, 2017.

[13] Metropolitan Museum, "Falcon figurine", Metropolitan Museum, "Falcon figurine", http://ww w.metmuseum.org/art/collection/search/544902, 2017.

[14] Getty Images, "Golden falcon that belongs to Queen Hetepheres I",http://www.gettyimages. com/detail/photo/27th-26th-century-b-c-egyptian-museum-old-high-res-stock-photography/ $96502824,2017$.

[15] J. Alicea, "Horus gold falcon's head with obsidian eyes", https://www.pinterest.se/pin/34325880 2826119597/

[16] Metropolitan Museum, "Necklace of Sithathoryunrt with the name of Senwosret II", http://www. metmuseum.org/toah/works-of-art/16.1.3/ , 2017.

[17] A. Hegab, "Faience amulet of a falcon, 12 ${ }^{\text {th }}$ Dynasty", https://www.pinterest.com/pin/4058 86985152871998/

[18] Metropolitan Museum, "Broad collar of Senebtisi", http://www.metmuseum.org/exhibitions/ view?exhibitionId=\%7B36BFD863-BD71-4D58-B1B2-F3F865084DBB\%7D\&oid=544168 2017.

[19] Metropolitan Museum, "Falcon wearing a Double Crown", http://www.metmuseum.org/art/ collection/search/544422?rpp=30\&pg=5\&ao=on\&ft=gold+egypt\&pos=131 , 2017.

[20] Lacma Collections, "Female fertility figurine", http://collections.lacma.org/node/245045

[21] J. Gentry, "Authentic ancient Egyptian artifacts, canopic jar", https://www.pinterest.com/pin/ 26951297742533578/

[22] Tour Egypt, "Pectoral in the shape of a falcon", http://www.touregypt.net/museum/tutl60.htm 2017.

[23] The Walters, "Hawk-falcon", http://art.thewalters.org/detail/23258/hawk-falcon/Wikipedia, "Statue of Horus from the reign of Amenhotep II", https://en.wikipedia.org/wiki/Horus\#/ media/File:Horus_R01.jpg, 2017.

[24] T. Telford, "Colossal statue of Ramses II as a child protected by Horus", https://www.pinterest. $\mathrm{com} / \mathrm{pin} / 146578162851234540 /$

[25] S. Garcia, "Ramses II and Hurun", http://egiptologia.com/ramses-ii-y-hurun/ , 2017.

[26] A. Hegab, "Canopic jar belonging to Psusennse I with head of Qebehsenuef", https://www. pinterest.com/pin/405886985146701497/

[27] A. Hegab, "Painted wooden falcon, Late Period", https://www.pinterest.com/pin/4058869851 $51626960 /$

[28] Louvre, "Statuette of Taharqa and falcon", http://www.louvre.fr/en/oeuvre-notices/statuettetaharqa-and-falcon-god

[29] Christies, , "An Egyptian bronze falcon, Late Period to Ptolemaic Period", http://www.christies. com/lotfinder/ancient-art-antiquities/an-egyptian-bronze-falcon-standard-late-period-5627934details.aspx ?from=salesummary\&pos=86\&intObjectID=5627934\&sid=ed54993a-4191-40418ea6-aa9bb0928cdd , 2017.

[30] Christies, "An Egyptian bronze Horus falcon", http://www.christies.com/lotfinder/ancient-artantiquities/an-egyptian-bronze-horus-falcon-late-period-5546870-details.aspx ?from=salesu mmary\&pos=60\&intObjectID=5546870\&sid=b0d6b37b-a98a-4603-9a05-136914c8ce1a , 2017. 
Galal Ali Hassaan "Mechanical Engineering in Ancient Egypt, Part 45: Birds Statues (Falcon and Vulture)"

[31] Metropolitan Museum, "Horus protecting King Nectanebo II", http://www.metmuseum.org/ toah/works-of-art/34.2.1/, 2017.

[32] Wikipedia, "Nekhbet", https://en.wikipedia.org/wiki/Nekhbet, 2017.

[33] A. Hegab, "Vulture jar, Egyptian Middle Kingdom", https://www.pinterest.com/pin/40588698 5140122804/

[34] Tour Egypt, "Pectoral of Mereret", http://www.touregypt.net/egyptmuseum/egyptian_museu mr3.htm , 2017.

[35] Egiptologia, "Queen Ahhotep's vulture bangle", http://egiptologia.com/brazalete-del-buitre-dela-reina-ahhotep/ , 2016.

[36] A. Hegab, "Pectoral of Nekhbet from the tomb of Tutankhamun", https://www.pinterest.com/ pin/405886985151218472/

[37] T. McManus, "Ceremonial gilded wooden shield from the tomb of King Tutankhamun", https://www.pinterest.com/pin/420664421416361263/

[38] S. Fcitizen, "Inlaid diadem with vulture and cobra", http://sfcitizen.com/blog/2009/06/26/tut-atthe-de-young-know-your-boy-king-1-diadem-with-vulture-and-cobra/

[39] E. Art, "Gold amulet in the form of a vulture", http://elogedelart.canalblog.com/archives/2010/ 04/22/17656460.html

\section{AUTHOR'S BIOGRAPHY}

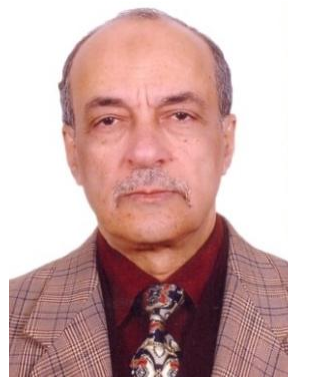

\section{Galal Ali Hassaan}

- Emeritus Professor of System Dynamics and Automatic Control.

- Has got his B.Sc. and M.Sc. from Cairo University in 1970 and 1974.

- Has got his Ph.D. in 1979 from Bradford University, UK under the supervision of Late Prof. John Parnaby.

- Now with the Faculty of Engineering, Cairo University, EGYPT.

- Research on Automatic Control, Mechanical Vibrations, Mechanism Synthesis and History of Mechanical Engineering.

- Published more than 190 research papers in international journals and conferences.

- Author of books on Experimental Systems Control, Experimental Vibrations and Evolution of Mechanical Engineering.

- Chief Editor of the International Journal of Computer Techniques.

- Member of the Editorial Board of some international journals including IJEERT.

- Reviewer in some international journals.

Scholars interested in the authors publications can visit: http://scholar.cu.edu.eg/galal 